\title{
Investigation of vegetative growth, yield and fruit quality characteristics of 'Hafif Çukurgöbek' loquat cultivar grafted on different quince rootstocks
}

\author{
Farklı ayva anaçları üzerine aşılı 'Hafif Çukurgöbek' yenidünya çeşidinin vejetatif \\ büyüme, verim ve meyve kalite özelliklerinin incelenmesi
}

\author{
Sibel AKKUŞ ${ }^{1}$ iD A. Aytekin POLAT ${ }^{2 *}$ iD \\ ${ }^{1}$ Hatay Mustafa Kemal University, Faculty of Agriculture, Department of Horticulture, Antakya, 31034 Hatay, Turkey \\ ${ }^{1}$ https://orcid.org/0000-0003-4783-6940; ${ }^{2}$ https://orcid.org/0000-0002-5701-4767
}

To cite this article:

Akkuş, S. \& Polat, A.A. (2021). Investigation of vegetative growth, yield and fruit quality characteristics of 'Hafif Çukurgöbek' loquat cultivar grafted on different quince rootstocks. Harran Tarım ve Gıda Bilimleri Dergisi, 25(3): 279-286.

DOI: 10.29050/harranziraat.910900

*Address for Correspondence: A. Aytekin POLAT

e-mail:

aapolat@mku.edu.tr

Received Date:

06.04.2021

Accepted Date:

14.07.2021

( ) Copyright 2018 by Harran University Faculty of Agriculture. Available on-line at www.dergipark.gov.tr/harranziraat

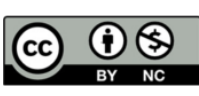

This work is licensed under a Creative Commons
Attribution-Non Commercial

\section{ABSTRACT}

'Hafif Çukurgöbek' loquat budded on three quince rootstock (BA-29, A, and C) were evaluated in 2018 and 2019 in Hatay, Turkey. Fruit ripening was the earliest in BA-29 rootstock in both years. The highest fruit weight was obtained from Quince-C rootstock and followed by BA-29 rootstock, and Quince-A rootstock. Quince-C rootstock yielded significantly higher values in terms of seed number, seed weight, and flesh/seed ratio. BA29 and Quince-A rootstocks had similar values in terms of total soluble solids, while Quince$C$ rootstock had the lowest value. Differences between the rootstocks in terms of titratable total acidity and $\mathrm{pH}$ were not found to be statistically significant. Quince- $\mathrm{C}$ rootstock gave higher values in terms of annual shoot length, scion and rootstock diameter compared to Quince-A and BA-29 rootstocks. The differences between the rootstocks in terms of vegetative parameters were found to be statistically significant at $1 \%$ level. Our preliminary data indicate that dwarfing quince rootstocks can be used in intensive plantings of loquat. In this study, BA-29 and Quince $C$ rootstock performed better than Quince-A. Considering yield and fruit quality based on total soluble solid, BA-29 rootstock seems the best choice.

Key Words: Loquat, Quince rootstocks, Fruit quality, Vegetative growth, Yield

öz

Üç ayva anacına (BA-29, A ve C) aşılanmış Hafif Çukurgöbek yenidünya çeşidi, Hatay'da(Türkiye) 2018 ve 2019 yıllarında değerlendirilmiştir. Meyve olgunlaşması, her iki yılda da BA-29 anacında en erken olmuştur. En yüksek meyve ağırlığı Quince-C anacından elde edilmiş ve bunu BA-29 anacı ve Quince-A anaçları takip etmiştir. Tohum sayısı, tohum ağırlığı ve et / tohum oranı bakımından Quince-C anacı önemli ölçüde daha yüksek değerler vermiştir. Suda çözünebilir kuru madde bakımından BA-29 ve Quince-A anaçları benzer değerlere sahipken, Quince-C anacı en düşük değere sahip olmuştur. Titre edilebilir toplam asitlik ve $\mathrm{pH}$ açısından anaçlar arasındaki farklılıklar istatistiksel olarak anlamlı bulunmamıştır. Quince-C anacı, Quince-A ve BA-29 anaçlarına göre yıllık sürgün uzunluğu, anaç ve kalem çapı açısından daha yüksek değerler vermiştir. Vegetatif parametreler açısından anaçlar arasındaki farklılıklar, istatistiksel olarak \% 1 düzeyinde önemli bulunmuştur. Ön verilerimiz, bodur ayva anaçlarının sık dikim yenidünya yetiştiriciliğinde kullanılabileceğini göstermektedir. Bu çalışmada, BA-29 ve Quince C anaçları, Quince-A'dan daha iyi performans göstermiştir. Toplam çözünür kuru maddeye göre meyve kalitesi ve verim göz önüne alındığında, BA-29 anacı en iyi seçenek gibi görünmektedir.

Anahtar Kelimeler: Yenidünya, Ayva anaçları, Meyve kalitesi, Vejetatif büyüme, Verim 


\section{Introduction}

World production of loquat (Eriobotrya japonica Lindl.) is about 565 thousand t. China is in first place with a production of 453.6 thousand $t$ from 118,270 ha, followed by Spain, 41.4 thousand t from 3,230 ha, while Turkey ranks fourth with of 16 thousand $t$ from 986 ha (Polat, 2018). Since loquat ripens before most fruit species demand and prices are high (Polat and Kaşka, 1991; Özçagıran et al., 2011).

Loquat trees are 5-10 $\mathrm{m}$ tall and form a large crown with high cultivation and harvesting costs. The most effective method of controlling plant height is the use of dwarfing rootstocks.

Dwarfed trees reduce costs of pruning, spraying, thinning and harvest and with high populations have high yields with excellent fruit quality (Polat et al., 2003, 2004). Quince, pyracantha and loquat seedling have been used as rootstocks (Ochse et al., 1961; Hizal et al., 1982). Quince rootstocks slow scion growth reducing tree size by 20 to $25 \%$ as compared to loquat seedlings, increase earliness, and increase fruit quality and size (Demir, 1987; Polat and Kaşka, 1992a, b; Polat, 1995). Although quince rootstocks have dwarfing effect on loquat, the effects of quince rootstocks on the fruit yield and quality have not been evaluated on Turkish cultivars. The present study evaluated yield and quality of 'Hafif Çukurgöbek' loquat budded on Quince-A, Quince-C and BA 29 rootstocks. Here, the first results were presented.

\section{Material and Methods}

\section{Material}

This study was carried out in Hatay $\left(36^{\circ} 12^{\prime} \mathrm{E}\right.$, $36^{\circ} 52^{\prime} \mathrm{N}, 80$ m.a.s.I.), Turkey during 2018 and 2019. The experiment area has a typical Mediterranean climate; the yearly average temperature is $18.3^{\circ} \mathrm{C}$, with $1168 \mathrm{~mm}$ precipitation which primarily falls during winter and spring. The soil is alkaline $(\mathrm{pH}: 7.76)$, with very little lime (\% 2.4), moderate salt (EC microsiemens: 446) and sandy-loam (\%57.37 sand, \%25.32 loam and \%12 clay).

One-year old 'Hafif Çukurgöbek loquat trees budded on BA-29, Quince-A and Quince-C quince rootstocks were planted (Figure 1 ) at spacings of $1.0 \times 0.5 \mathrm{~m}$ (2000 trees/da) in January 2017, drip irrigated, with standard cultural practices. Trees were trained according to open-centre system.

\section{Rootstocks and varieties}

The BA-29, Quince-C and Quince-A rootstocks used in the experiment are rootstocks were selected at the East Malling Research station, UK.

'Hafif Çukurgöbek' is an early cultivar with medium-sized, orange-colored fruit, very tasty and sweet was selected in Turkey (Demir, 1987). It is self-fertile and resistant to scab incited by Spilocaeae eriobotryae. 


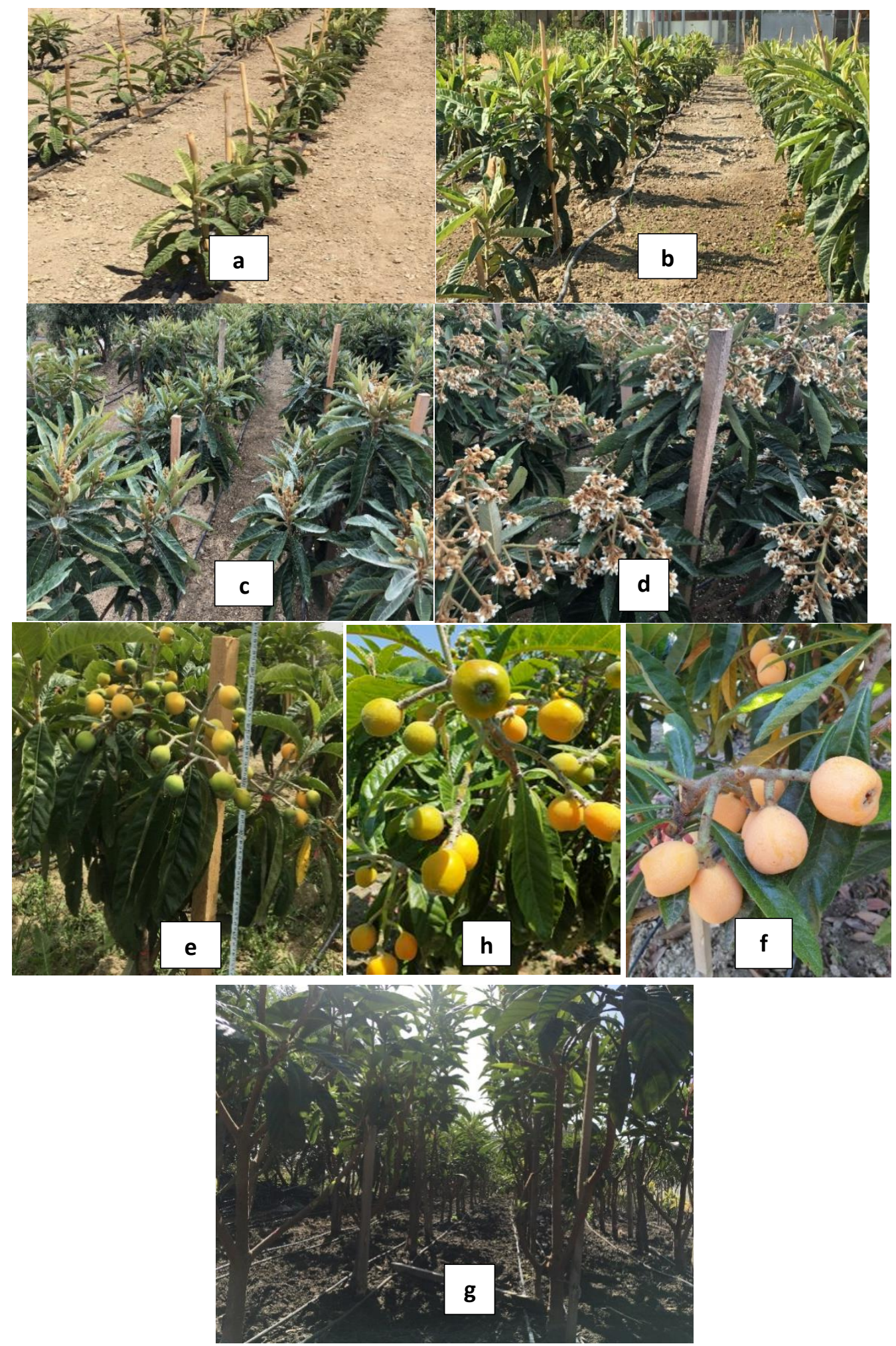

Figure 1. Successive steps of high density orchard of 'Hafif Cukugöbek' loquat. (a) Planting; (b) Irrigation and tillage; (c) Branches of flower cluster begin to elongate; (d) Full bloom; $(e, f, g)$ Fruit maturity stages; (h) Current condition.

\section{Method}

The experiment was arranged according to a completely randomized designed with 5 replications and 6 plants were used in each replicate.

\section{Pomological characteristics}

To determine fruit quality, 50 fruits (10 fruits from each replicate) were randomly sampled from each cultivar/rootstock combination and physical and chemical measurements and analyzes were carried out including fruit weight (g), fruit dimensions $(\mathrm{mm})$, seed weight $(\mathrm{g})$, number of seeds (pieces), flesh seed ${ }^{-1}$ ratio (\%), total soluble solids (TSS) (\%), titratable total acidity (TA) (\%), pH.

\section{Vegetative growth}

Vegetative growth of trial plants was measured 
at three month intervals starting from February 2018.

\section{Annual shoot length $(\mathrm{cm})$}

Four shoots from each plant were measured from 4 sides of the plants.

\section{Trunk diameter $(\mathrm{mm})$}

Scion and rootstock trunk diameters $15 \mathrm{~cm}$ below and above of bud union) were measured in all plants with a digital caliper sensitive to 0.01 $\mathrm{mm}$.

\section{Bud union-first branching $(\mathrm{cm})$}

The distance between the bud union and the first branching on the scion trunk was measured.

\section{First branching - longest shoot $(\mathrm{cm})$}

The distance between the first branching and the top of the longest shoot on the scion trunk was measured.

\section{Bud union-longest shoot $(\mathrm{cm})$}

The distance between the bud union and the top of the longest shoot on the scion trunk was measured.

\section{Yield}

Yield per tree ( $\left.\mathrm{kg} \mathrm{plant}^{-1}\right)$

Fruit weight of each plant was determined.

Yield per trunk unit cross-sectional area $\left(\mathrm{g} \mathrm{mm}^{-2}\right)$

Stem cross section was measured $5 \mathrm{~cm}$ above the budding point in May of each year.

\section{Yield per area (ton/da)}

Considering the planting distances in the experiment, the yield for area-basis was calculated by multiplying yield per tree with the number of plants.

\section{Data analysis and statistics}

Analysis of variance (Anova) was used based on a completely randomised design, and the means were separated by Tukey's HSD multiple comparison test at 0.01 (Steel and Torrie, 1980).
The percentage values were transformed to increase normality by the angle transformation before submitting the data to the analysis of variance.

\section{Results and Discussion}

\section{Fruit quality}

The results of the statistical analysis made according to the two-year averages are given in Table 1.

According to the two-year averages, the highest values in terms of fruit weight and fruit size were obtained from plants with rootstock Quince-C, followed by BA-29. The lowest values were obtained from was Quince-A. This difference between the rootstocks was found to be statistically significant at $5 \%$ level (Table 1 ). Quince-C rootstock also gave higher values in terms of seed number and seed weight ratio than the other two rootstocks. Differences between the rootstocks were be statistically significant. The highest value in terms of flesh seed ${ }^{-1}$ ratio was determined in Quince-A rootstock but the difference between the rootstocks was not significant. In terms of total acidity and $\mathrm{pH}$, close values were obtained from all three rootstocks.

In loquat cultivation, many factors such as cultivar, soil structure, climate conditions and picking time affect the physical and chemical properties of the fruit (Toker et al., 2010). In the previous studies, the fruit weight of 'Hafif Çukurgöbek' on loquat seedling was between $20.45 \mathrm{~g}$ and $39.70 \mathrm{~g}$ (Paydaş et al., 1992; Polat et al., 2004, 2005 and 2010; Polat and Caliskan, 2011). Durgac et al. (2006) found the fruit weight in 4 loquat cultivars to be between $22.55 \mathrm{~g}$ and $25.68 \mathrm{~g}$. Fruit weights determined in our study are lower than the values found in previous studies except for that of Durgac et al. (2006). This difference may have resulted from the fact that the plants in this experiment were younger than the plants in other studies. Fruit size is an important criterion that can vary depending on tree age and fruit set (Durgaç et al., 2006).

In previous studies, researchers measured fruit 
width as between $36.79 \mathrm{~mm}$ and $40.10 \mathrm{~mm}$; determined the fruit length as between $37.3 \mathrm{~mm}$ and $42.40 \mathrm{~mm}$ (Polat et al., 2005 and 2010; Polat and Caliskan, 2011). Durgac et al (2006) determined the fruit width to be between 32.83 $\mathrm{mm}$ and $36.51 \mathrm{~mm}$, and the fruit length to be between 33.84 and $44.35 \mathrm{~mm}$. The fruit widths determined in our study, while being similar to that of Durgac et al (2006), are different from the findings of other studies. In terms of fruit length, it was partially similar. Our seed weight values are between 4.50-5.71 g. In the previous studies, seed weight was found to be between 4.0 and $7.73 \mathrm{~g}$ (Polat et al., 2004, 2005; Durgac et al., 2006; Polat et al., 2010; Polat and Caliskan, 2011). Our seed weight values were found to be lower than those of researchers except for Durgac et al (2006) and Polat and Çalışkan (2011). The number of seeds was determined to be between 3.34-3.82. In previous studies, the number of seeds was between 2.4 and 4.16 (Polat et al., 2004, 2005 and 2010; Durgac et al., 2006; Polat and Çalışkan, 2011). The data of the combinations examined show similarities with the data determined in other studies. The amount of flesh of the fruit is considered as one of the important criteria in fruit quality, and in determining this, the flesh/seed ratio is accepted as a criterion. While this rate was determined to be between 3.21-2.89 in the study, this value was measured as between 3.43 and 5.42 in previous studies (Paydaş et al., 1992; Polat et al., 2004, 2005 and 2010; Durgac et al., 2006). The values obtained in our study are partially similar to those in previous studies. In our study, BA-29 rootstock gave higher values in terms of total soluble solids than the other two rootstocks. In previous studies, researchers measured TTS as between $8.05-12.80 \%$. The values determined in our study are generally similar to those of previous studies. In this study, titratable acid was determined to be between $0.75-0.81$ and $\mathrm{pH}$ as 3.42-3.79, while in previous studies, acidity was 0.63-9.92 and $\mathrm{pH}$ was measured to be between 3.29 and 4.5 (Polat et al., 2004, 2005; Durgac et al., 2006; Polat et al., 2010; Polat and Caliskan, 2011). Our findings are lower than the values of Polat et al (2010) and higher than the values of Polat et al (2005). TTS, acidity and $\mathrm{pH}$ are affected by such factors as time of picking, climatic conditions, cultivars, etc.

Table 1. The effects of quince rootstocks on fruit quality parameters of the Hafif Çukurgöbek loquat cultivar (2018-2019 average)

\begin{tabular}{|c|c|c|c|c|c|c|c|c|c|}
\hline Rootstock & $\begin{array}{c}\text { Fruit } \\
\text { weight } \\
\text { (g) }\end{array}$ & $\begin{array}{l}\text { Fruit } \\
\text { width } \\
(\mathrm{mm})\end{array}$ & $\begin{array}{l}\text { Fruit } \\
\text { length } \\
(\mathrm{mm})\end{array}$ & $\begin{array}{c}\text { Seed } \\
\text { weight } \\
\text { (g) }\end{array}$ & $\begin{array}{c}\text { Seed } \\
\text { number } \\
\text { per fruit }\end{array}$ & $\begin{array}{c}\text { Flesh/seed } \\
\text { ratio }\end{array}$ & $\begin{array}{c}\text { Soluble } \\
\text { solids } \\
(\%)\end{array}$ & $\begin{array}{c}\text { Acidity } \\
(\%)\end{array}$ & $\mathrm{pH}$ \\
\hline Quince-A & $18.80 b^{(x)}$ & $24.39 \mathrm{~b}$ & $27.16 \mathrm{~b}$ & $4.50 \mathrm{~b}$ & $3.34 \mathrm{~b}$ & 3.21 & $12.04 \mathrm{ab}$ & 0.81 & 3.79 \\
\hline Quince-C & $23.33 \mathrm{a}$ & $34.21 \mathrm{a}$ & $37.23 \mathrm{a}$ & $5.71 \mathrm{a}$ & $3.82 \mathrm{a}$ & 3.09 & $10.32 b$ & 0.74 & 3.53 \\
\hline BA-29 & $20.22 a b$ & $32.71 \mathrm{a}$ & $35.96 \mathrm{a}$ & $5.27 \mathrm{ab}$ & $3.58 a b$ & 2.89 & $12.36 \mathrm{a}$ & 0.75 & 3.42 \\
\hline HSD & $*$ & $*$ & $* *$ & $* *$ & $* *$ & $N S^{(y)}$ & $*$ & NS. & NS. \\
\hline
\end{tabular}

${ }^{(x)}$ : Mean separation by Tukey's HSD at $p<0.05\left(^{*}\right)$ and at $p<0.01\left({ }^{* *}\right)$ level.

(v) NS: Not significant

\section{Vegetative growth}

In terms of annual shoot length, scion and rootstock trunk diameters, Quince-C rootstock showed stronger growth and gave higher values than Quince-A and BA-29 rootstocks (Figure 2 and 3).

The Quince-A rootstock had lower values than the other two rootstocks except for the distance between the budding point and the first branching of the stem. In terms of the distance between the budding point and the first branching of the trunk, Quince-A gave the highest value, followed by BA29 , and Quince-C gave the lowest value (Figure 4). 
Akkuş and Polat, 2021. Harran Tarım ve Gıda Bilimleri Dergisi, 25(3): 279-286

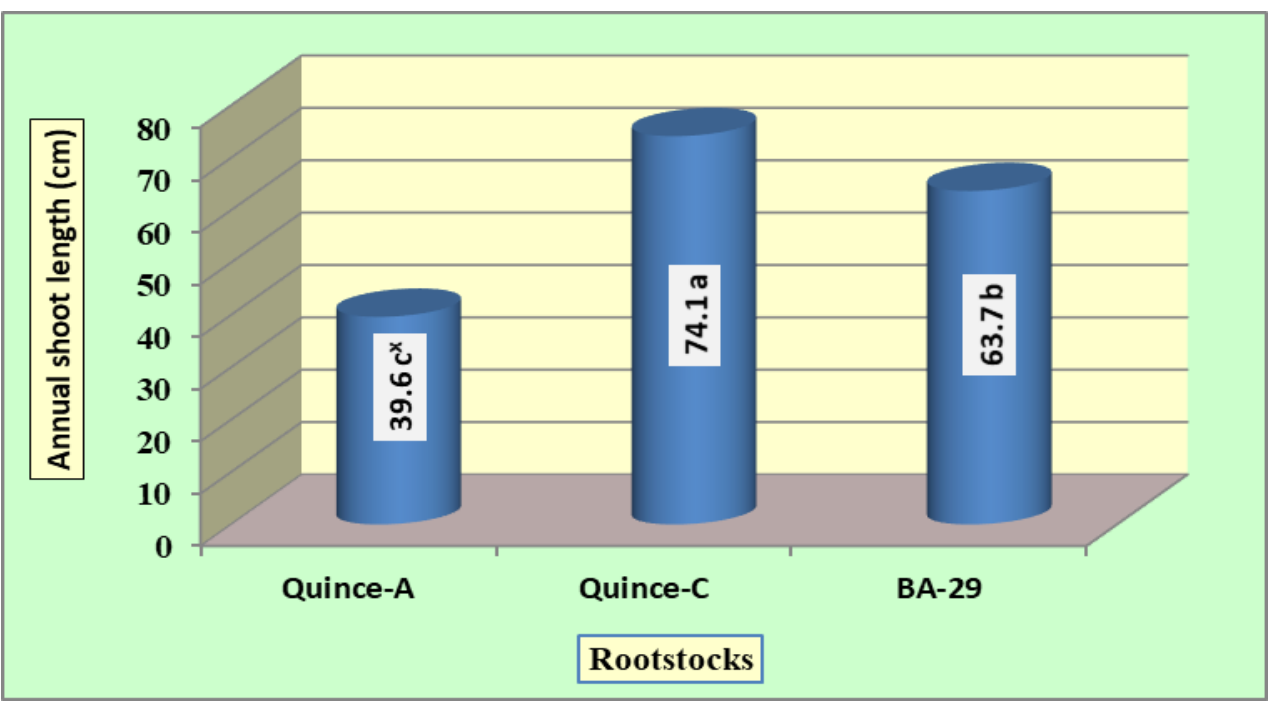

Figure 2. Average annual shoot length of 'Hafif Çukurgöbek' loquat budded on quince rootstocks in 2018-2019.

(x): Means followed by different lowercase letters indicate significant difference by Tukey's test at $p<0.01$ level.

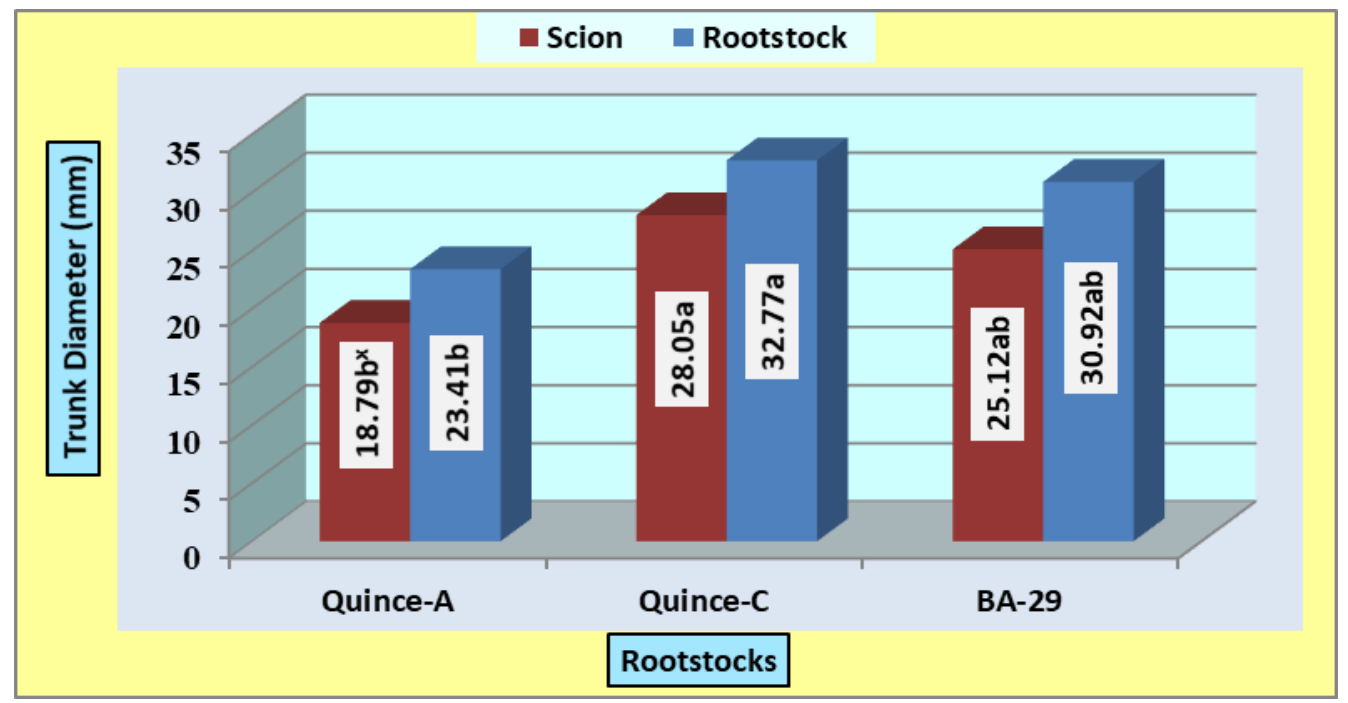

Figure 3. Average scion and rootstock trunk diameter of 'Hafif Çukurgöbek' loquat budded on quince rootstocks in 2018-2019.

$(\mathrm{x})$ : Means followed by different lowercase letters within same parameter are indicate significant difference by Tukey's test at $p<0.01$ level.

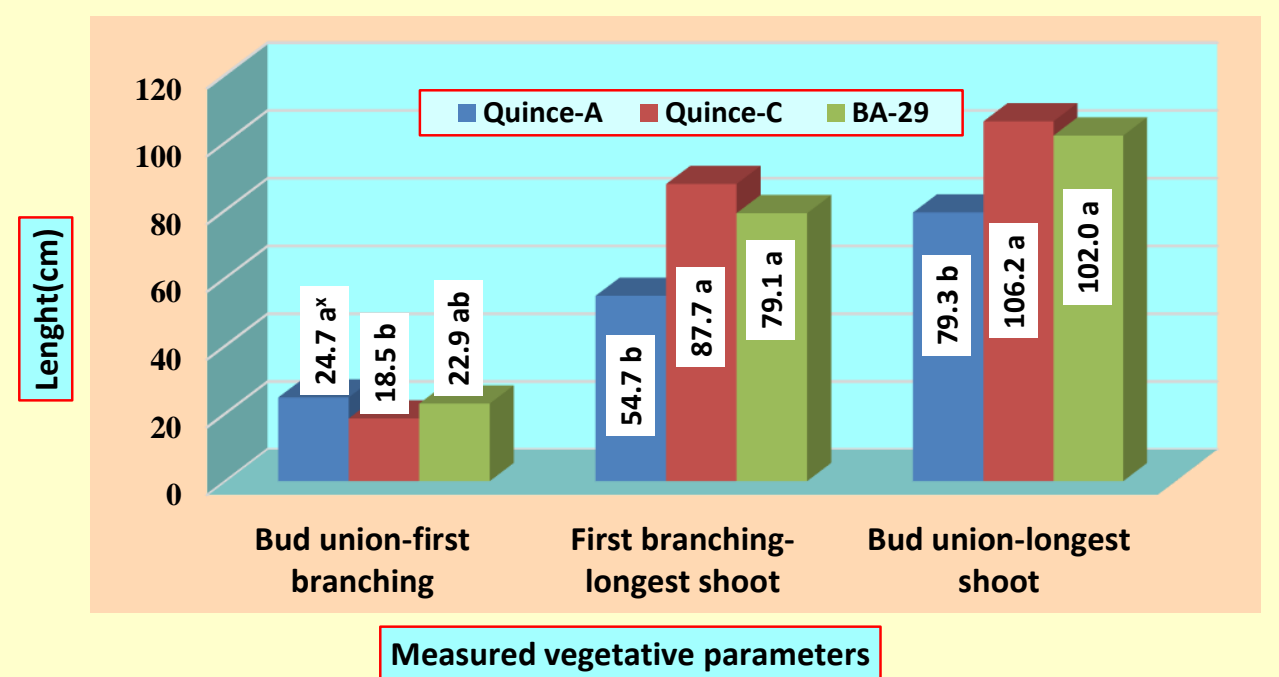

Figure 4. Some vegetative growth parameters of 'Hafif Çukurgöbek' loquat budded on quince rootstocks (2018-2019 average).

(x): Means followed by different lowercase letters within same parameter are indicate significant difference by Tukey's test at $\mathrm{p}<0.01$ level. 
The differences of rootstocks in terms of vegetative parameters were found to be statistically significant at $1 \%$ level.

In the study, it was determined that the first branching in the plants budded on the Quince-C rootstock was lower than the other rootstocks, while it also formed larger plants compared to the plants budded on other rootstocks. Quince-A rootstock, which has the lowest values, has been found to form smaller plants than other rootstocks.

In previous studies, Polat and Kaşka (1992a) reported the shoot growth as an average of 23.4 $\mathrm{cm}$ in buddings on the Quince-A rootstock. Polat (1995), in the measurements made between 1993 and 1995, measured the scion diameter in the loquat (cvs. Akko-XIII and Armut Şekilli) saplings whose rootstocks were Quince - A as $18.24 \mathrm{~mm}$, $30.15 \mathrm{~mm}$ and $36.39 \mathrm{~mm}$ and the sapling height as $74.3 \mathrm{~cm}, 120.2 \mathrm{~cm}$ and $124.4 \mathrm{~cm}$, respectively. The values obtained from our study were lower than the values measured by Polat and Kaşka (1992a) and Polat (1995). It is thought that this is due to the effect of the difference in the cultivar and rootstocks of the trial material plants as well as the age difference.

\section{Yield}

The yields of Hafif Çukurgöbek loquat on different quince rootstocks are given in Table 2 .

Table 2. The effects of quince rootstocks on fruit yield of Hafif Çukurgöbek loquat (average of 2018-2019)

\begin{tabular}{lccc}
\hline Rootstock & $\begin{array}{c}\text { Yield } \\
\left.\text { (g plant }^{-1}\right)\end{array}$ & $\begin{array}{c}\text { Yield per unit } \\
\text { trunk cross- } \\
\text { sectional area } \\
\left(\mathrm{g} \mathrm{mm}^{-2}\right)\end{array}$ & $\begin{array}{c}\text { Yield } \\
\text { (ton da }^{-1} \text { ) }\end{array}$ \\
\hline Quince-A & $279.35 \mathrm{~b}^{(\mathrm{x})}$ & $0.690 \mathrm{~b}$ & $0.558 \mathrm{~b}$ \\
Quince-C & $632.50 \mathrm{a}$ & $0.895 \mathrm{a}$ & $1.265 \mathrm{a}$ \\
BA-29 & $640.00 \mathrm{a}$ & $0.921 \mathrm{a}$ & $1.330 \mathrm{a}$ \\
\hline HSD & $* *$ & $* *$ & $* *$ \\
\hline
\end{tabular}

$(x)$ : Means followed by different lowercase letters within a column are indicate significant difference by Tukey's test at $\mathrm{p}<0.01(* *)$ level.

According to the two-year averages, the highest yield values ( $640 \mathrm{~g}$ plant $^{-1}$ and $0.921 \mathrm{~g} \mathrm{~mm}^{-2}, 1.33$ ton $\mathrm{da}^{-1}$, respectively) in terms of all three yield per plant, yield per unit trunk cross-sectional area and yield per decare were obtained from the BA-29 rootstock. This was followed by Quince-C rootstock with values of $632 \mathrm{~g}$ plant $^{-1}, 0.895 \mathrm{~g} \mathrm{~mm}^{-}$ 2 and 1.26 ton da-1. Quince-A rootstock gave the lowest values in terms of all three yield elements. This difference between the rootstocks was found to be statistically significant at $1 \%$ level (Table 2).

Only four references of high density loquat orchards have been found in the literature. Insero et al. (2004) compared ten cultivars grafted on BA29 quince and spaced $4 \times 2 \mathrm{~m}$. Average cumulative yield from 4 th to 8 th season was about $45 \mathrm{t} / \mathrm{ha}$. With similar tree density but spacing loquats at $3 \times$ $3 \mathrm{~m}$, Polat et al. (2004) have compared 'HÇG', 'Sayda' and 'Golden Nugget' budded on loquat seedlings. They obtained a mean productivity of $7165 \mathrm{~kg} / \mathrm{ha}$ during the first three harvests. After two additional seasons, Polat et al. (2005) have published that orchard productivity had raised to $9311 \mathrm{~kg} / \mathrm{ha} /$ year. In the study by Hueso et al. (2007), to check suitability of loquat to extreme intensification it was designed an orchard of 'Magdal' budded on quince $C$ at a distance of $2.5 \times$ $1.7 \mathrm{~m}$ (2353 trees per ha). First yield was reached an average of $2.8 \mathrm{~kg} /$ tree on season 2003/2004. Second yield in April 2005 was reached a worthy level of $10.8 \mathrm{~kg} /$ tree (25 t/ha). Third yield was limited to $13.0 \mathrm{~kg} /$ tree (30 t/ha).

\section{Conclusion}

The tall and wide crown structure of loquat suggests that high populations of dwarfed trees achieved with dwarfing rootstocks would increase yields per unit area and facilitate cultural practices including harvest. However, studies of dwarfed loquat produced with quince rootstocks are rare in Turkey. In this study, the effects of three quince rootstocks (Quince A, Quince B, and BA-29) on vegetative growth, fruit yield and quality of 'Hafif Çukurgöbek' loquat spaced $0.5 \times 1.0 \mathrm{~m}$ and planted in January 2017 were compared in 2018 and 2019.

Yield per plant were highest with Quince-C, followed closely by B-29 but yields with Quince-A rootstock were much lower. However, fruit soluble solid was highest with B-29 closely followed by Quince A and lowest with Quince C. Yield per unit 
trunk cross-sectional highest with Quince $C$ and B29 followed by Quince A. Fruit weight and fruit size were significantly highest with Quince-C rootstock, followed by BA-29 and Quince-A. Shoot length, scion and rootstock diameter were greatest with Quince-C.

Our preliminary data indicate that dwarfing quince rootstocks can be used in intensive plantings of loquat. In this study, BA-29 and Quince $C$ rootstock performed better than Quince-A. Considering yield and fruit quality based on total soluble solid, BA-29 rootstock seems the best choice.

\section{Acknowledgements}

We gratefully acknowledge the Research Grant (18-YL-027) of Coordinatorship of Scientific Research Projects, Hatay Mustafa Kemal University. We also thank Professor Jules Janick, Purdue university, USA, for reviewing an earlier version of the manuscript.

Conflict of Interest: Authors have declared no conflict of interest.

Author Contributions: AAP have designed the study and SA have collected the data. SA executed the experiment with the help of by AAP. AAP wrote the article. All authors have read, revised, and approved the manuscript.

\section{References}

Demir, S. (1987). Yenidünya Yetiştiriciliği. T.C. Tarım Orman ve Köyişleri Bakanlığı Antalya Narenciye Araştırma Enstitüsü Müdürlüğü. Genel Yayın, 12, 31s

Durgaç, C. Polat, A.A. \& Kamiloğlu, O. (2006). Determining Performances of Some Loquat (Eriobotrya japonica) Cultivars Under Mediterranean Coastal Conditions in Hatay, Turkey. New Zealand Journal of Crop and Horticultural Science, 34: 225-230

Hızal, A.Y.Ö., Paköz, M., \& Demir, Ş. (1982). Akdeniz Bölgemiz için Bazı Subtropik Meyvelerde Yetiştirme Sorunları. Bahçe Bitkileri Yetiştiriciliğinde Sorunlar, Çözüm Yolları ve Yapılması Gereken Araştırmalar Simpozyumu, 9-13 Nisan,1979, İncekum, Alanya, s: 376-403
Hueso, J.J., Cañete, M.L., \& Cuevas, J. (2007). High density loquat orchards: Plant selection 64 and management. Acta Horticulturae, 750: 349-353.

Insero, O., Rega, P., \& De Luca, A. (2004). Comparison among ten loquat cultivars in Campania area. Options Méditerranéennes Série A 58:67-70.

Ochse, J.J., Soule, JrMJ., Diskman, M.J., \& Wehlburg, C. (1961). Tropical and Subtropical Agriculture, Volume I. The Macmillan Company. New York. p. 721-723

Özçağıran, R., Ünal, A., Özeker, E., \& İsfendiyaroğlu, M. (2011). Ilıman Iklim Meyve Türleri: Yumuşak Çekirdekli Meyveler Cilt-II. Ege Üniversitesi Yayınları, Ziraat Fakültesi Yayınları, No: 556, İzmir

Paydaş, S., Kaşka, N., Polat, A.A., \& Gübbük, H. (1992). Adaptation of some local and foreign loquat (Eriobolrya japonica Lindl.) cultivars under Adana ecological conditions. $1^{\text {st }}$ Turkish National Horticultural Congress Volume 1: 509-513. İzmir, Turkey

Polat, A.A., \& Kaska, N. (1991). Investigation on the determination of most suitable buddings time and method for the loquat (Eriobotrya japonica Lindl.) under Adana ecological conditions. Turkish Journal of Agriculture and Forestry 15, 975-986

Polat, A.A., \& Kaska, N. (1992a). An investigation on the usage of Quince-A as a rootstock for loquat. Turkish Journal of Agriculture and Forestry 16, 745-755

Polat, A.A., \& Kaska, N. (1992b). Determination of budding success in loquats budded on Quince- $C$ rootstock. Bahçe 21, 9-11

Polat, A.A. (1995). The effects of Quince-A rootstock on vegetative growth of loquat plants. Derim 12, 84-88

Polat, A.A., Durgaç, C., Kamiloğlu, Ö., \& Çalışkan, O. (2003). Sık Dikim ve Örtüaltı Yetiştirme Tekniklerinin Yenidünyalarda Erkencilik Verim ve Kaliteye Etkilerinin Belirlenmesi. TÜBITAK Tarım, Orman ve Gıda Teknolojileri Araştırma Grubu, ARP - 2336. s:68

Polat, A.A., Durgaç, C., \& Çalışkan, O. (2004). Effects of Different Planting Space on The Vegetative Growth, Yield and Fruit Quality of Loquat. Acta Horticulturae, 632:189-195

Polat, A.A., Durgac, C., \& Caliskan, O. (2005). Effect of protected cultivation on the precocity, yield and fruit quality in loquat. Scientia Horticulturae, 104:189-198

Polat, A.A., Caliskan, O., Serçe, S., Saraçoğlu, O., Kaya, C., \& Özgen, M. (2010). Determining Total Phenolic Content and Total Antioxidant Capacity of Loquat Cultivars Grown in Hatay. Pharmacognosy Mag., 6(21): 5-8

Polat, A.A., \& Caliskan, O. (2011). Effects of Planting Densities on Fruit Quality and Productivity of Loquat. Acta Horticulturae, 87:133-138

Polat, A.A. (2018). Loquat Production in Turkey: Present State and Future. LAP Lambert Academic Publishing, $69 \mathrm{p}$

Steel, R., \& Torrie, J.H. (1980). Principles and procedures of statistics. 2nd ed. New York, McGraw-Hill.

Toker, R., Gölükcü, M., Tokgöz, H., \& Tepe, S. (2010). Ülkemizde Yetiştiriciliği Yapılan Yenidünya (Eriobotrya japonica) Çeşitlerinin Bazı Kalite Parametrelerinin Belirlenmesi Üzerine Bir Araştırma. Gıda, 35 (4): 275282. 